\title{
PENGARUH WAKTU POLIMERISASI PADA PROSES PEMBUATAN POLIESTER DARI ASAM LEMAK SAWIT DISTILAT (ALSD)
}

\author{
Ahmad Rozi Tanjung*, Ida Ayuningrum, Renita Manurung \\ Departemen Teknik Kimia, Fakultas Teknik, Universitas Sumatera Utara, \\ Jl. Almamater Kampus USU Medan 20155, Indonesia \\ *Email: creator_ashura@students.usu.ac.id
}

\begin{abstract}
Abstrak
Asam Lemak Sawit Distilat (ALSD) dapat dijadikan bahan baku pembuatan poliester. Penelitian ini bertujuan untuk menghasilkan poliester dan menentukan pengaruh waktu reaksi pada polimerisasi metil ester ALSD. Tahapan proses yang dilakukan adalah tahap esterifikasi pada temperatur $70^{\circ} \mathrm{C}$, waktu reaksi 120 menit, rasio reaktan 1:8 (ALSD : metanol), konsentrasi katalis $\left(\mathrm{H}_{2} \mathrm{SO}_{4}\right) 1 \%(\mathrm{~b} / \mathrm{b})$; tahap polimerisasi pada temperatur $126-132{ }^{\circ} \mathrm{C}$, konsentrasi katalis $\left(B F_{3}\right.$-dietil eterat) 9,2\% (b/b), dengan variasi waktu reaksi polimerisasi 3, 4, dan 5 jam dan tahap poliesterifikasi pada temperatur 175-200 ${ }^{\circ} \mathrm{C}$, rasio reaktan (b/b) 1:1 (ME terpolimerisasi : etilen glikol), waktu reaksi 4 jam dan semua tahap dilakukan pada kecepatan pengaduk $150 \mathrm{rpm}$. Hasil penelitian pada tahap esterifikasi diperoleh metil ester dengan bilangan iodin 77,29 g I2/100 g, viskositas 6,90 cP, densitas 859,91 $\mathrm{kg} / \mathrm{m}^{3}$ dan analisis GC-MS menunjukkan kemurnian metil ester yaitu 82,23\% dengan berat molekul $267,97 \mathrm{~g} / \mathrm{mol}$. Penurunan bilangan iodin dari 77,29 $\mathrm{g} \mathrm{I}_{2} / 100 \mathrm{~g}$ hingga 63,45-61,14 g $\mathrm{I}_{2} / 100 \mathrm{~g}$ mengindikasikan bahwa proses polimerisasi telah berlangsung. Pada tahap poliesterifikasi dihasilkan poliester yang berbentuk gel, kental, bewarna coklat kehitaman dan bertekstur padat pada suhu ruangan, memiliki bilangan asam 13,13-21,65 mg KOH/g, viskositas 14,3-19,1 dPa.s, dan berat molekul 995,03-1.522,07 g/mol tergolong poliester dengan berat molekul rendah yang lebih cocok digunakan untuk aplikasi poliester termodifikasi. Analisis kromatogram GC menunjukkan kemurnian poliester yang dihasilkan yaitu sebesar 65,49\%.
\end{abstract}

Kata kunci: poliester, asam lemak sawit distilat, waktu reaksi polimerisasi, biodegradable polimer

\begin{abstract}
Palm Fatty Acid Distillate (PFAD) can be used as raw material for synthesis polyester. The aim of this research is to synthesis of polyester and to determine the effect of reaction time on polymerization methyl ester PFAD. The esterification stage was done at temperature $70^{\circ} \mathrm{C}$, reaction time 120 minute, reactant ratio 1:8 (PFAD: methanol), concentration of catalyst $\left(\mathrm{H}_{2} \mathrm{SO}_{4}\right) 1 \%(\mathrm{w} / \mathrm{w})$ $P F A D$; polymerization stage was done at temperature $126-132^{\circ} \mathrm{C}$, concentration of catalyst $\left(\mathrm{BF}_{3^{-}}\right.$ diethyl etherate) $9.2 \%(w / w)$, variation of polymerization reaction time 3,4 , and 5 hours; and polyesterification stage was done at temperature $175-200{ }^{\circ} \mathrm{C}$, reactant ratios $(\mathrm{w} / \mathrm{w})$ 1:1 (polymerized $M E$ : ethylene glycol), reaction time 4 hours and all of stage was stirred at $150 \mathrm{rpm}$. The results showed, in the esterification stage was obtained methyl ester with iodine value $77.29 \mathrm{~g} \mathrm{I}_{2} / 100 \mathrm{~g}$, viscosity $6.90 \mathrm{cP}$, density $859.91 \mathrm{~kg} / \mathrm{m}^{3}$ and analysis by using $G C-M S$ showed that the purity of methyl ester was $82.23 \%$ and molecular weight $267.97 \mathrm{~g} / \mathrm{mol}$. Decreasing in iodine value from $77.294 \mathrm{I}_{2}$ $\mathrm{g} / 100 \mathrm{~g}$ to $63.45-61.14 \mathrm{~g} \mathrm{I}_{2} / 100 \mathrm{~g}$ indicated that the polymerization process had taken place. In polyesterification stage was obtained gel polyester, viscous, dark brown colored solid at room temperature with acid value from 13.13 to $21.65 \mathrm{mg} \mathrm{KOH} / \mathrm{g}$, viscosity from 14.3 to $19.1 \mathrm{P}$, and molecular weight 995.03 to $1,522.07 \mathrm{~g} / \mathrm{mol}$ which is more suitable for application of modified polyester. Analysis by using GC showed that the purity of polyester is equal to $65.49 \%$.
\end{abstract}

Keywords: polyester, palm fatty acid distillate, polymerization reaction time, biodegradable polymer

\section{Pendahuluan}

Indonesia merupakan salah satu produsen minyak sawit terbesar di dunia [17]. Dalam pengolahan minyak kelapa sawit diperoleh beberapa turunan diantaranya adalah Asam Lemak Sawit Distilat (ALSD) [19].

Dengan meningkatnya produksi minyak sawit memberikan gambaran bahwa perolehan ALSD turut meningkat. ALSD sebagai hasil samping ini memiliki potensi yang cukup besar untuk digunakan sebagai bahan baku pembuatan produk poliester.

Poliester saat ini umumnya disintesis dari senyawa hidrokarbon yang tidak dapat diperbaharui. Poliester memiliki banyak kegunaan diantaranya untuk membuat botol, film, tarpaulin, kano, tampilan kristal cair, hologram, penyaring, serat dan sebagainya [10].

Saat ini, minyak nabati diharapkan dapat diterapkan sebagai bahan baku alternatif polimer berbasis minyak. Polimer-polimer ini mempunyai banyak kelebihan dibandingkan dengan polimer yang dibuat berbasis monomer minyak bumi yaitu sifatnya yang biodegradable.

Salah satu faktor penting dalam reaksi pembentukan suatu zat adalah waktu reaksi. Dalam reaksi pembentukan polimer, waktu reaksi polimerisasi merupakan tahap penentu laju 
pembentukan produk [9]. Oleh karena itu, penelitian tentang pengaruh waktu reaksi polimerisasi perlu dilakukan. Perumusan masalah dalam penelitian adalah bagaimana pengaruh variasi waktu reaksi polimerisasi terhadap kualitas dan kuantitas poliester yang dihasilkan dari ALSD. Tujuan penelitian adalah menghasilkan poliester dan menentukan pengaruh waktu reaksi polimerisasi terhadap poliester yang dihasilkan.

\section{Teori}

Poliester adalah suatu kategori polimer yang mengandung gugus fungsional ester dalam rantai utamanya [3]. Poliester umumnya dipersiapkan dengan proses polikondensasi yang melibatkan reaksi monomer diol dan diasam atau diester memproduksi air atau alkohol sebagai produk samping [12]. Poliester ALSD akan dihasilkan melalui reaksi esterifikasi, polimerisasi dan poliesterifikasi.

Esterifikasi dapat didefinisikan sebagai reaksi antara asam karboksilat dan alkohol. [16]. Esterifikasi merupakan reaksi reversibel. [11].

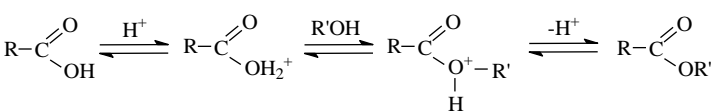

Gambar 1. Reaksi esterifikasi katalis asam [24]

Reaksi esterifikasi yang berkatalis asam berjalan lebih lambat namun metode ini lebih sesuai untuk minyak atau lemak yang memiliki kandungan asam lemak bebas relatif tinggi [8].

Reaksi polimerisasi merupakan reaksi penggabungan dari asam lemak tidak jenuh membentuk senyawa kompleks yang disebut dimer dan trimer [5]. Efisiensi katalis polimerisasi tergantung pada kekuatan asam kompleks [7]. Kompleks boron trifluorida-dietil eterat merupakan katalis yang efektif, lebih meyakinkan untuk ditangani dan menghasilkan warna polimer yang lebih cerah [4].

Mekanisme reaksi polimerisasi metil ester menjadi polimerik ester dengan katalis kompleks boron trifluorida adalah sebagai berikut:

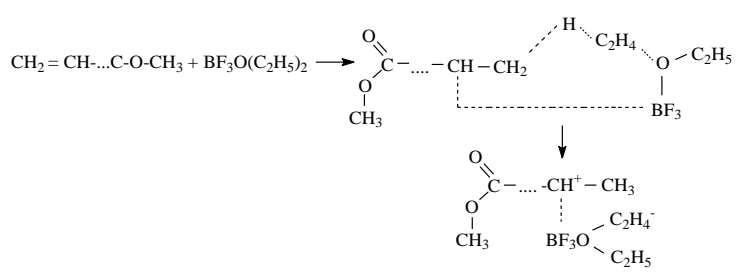

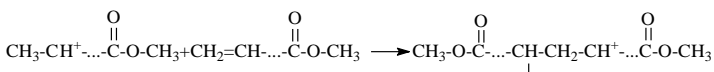

$$
\begin{aligned}
& \mathrm{CH}_{3}
\end{aligned}
$$

Gambar 2. Reaksi polimerisasi metil ester [20]

Metil ester terpolimerisasi direaksikan dengan etilen glikol untuk menghasilkan poliester. Selama berlangsungnya reaksi poliesterifikasi diusahakan terjadi penghilangan metanol atau air yang terbentuk sehingga akan meningkatkan kecepatan reaksi [20].

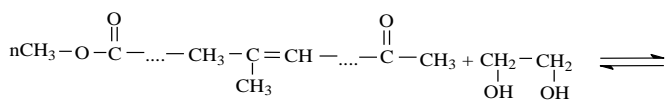

$$
\begin{aligned}
& { }_{\mathrm{nCH}}-\mathrm{O}\left[-\stackrel{\mathrm{O}}{\mathrm{C}}-\ldots . .-\mathrm{CH}=\mathrm{CH}_{2}-\ldots . . . \mathrm{C}-\mathrm{O}-\mathrm{CH}_{2}-\mathrm{CH}_{2}-\mathrm{O}-\right] \mathrm{nH}+(2 \mathrm{n}-1) \mathrm{CH}_{3} \mathrm{OH}
\end{aligned}
$$

\section{Gambar 3. Reaksi Poliesterifikasi Metil Ester dan Etilen Glikol [20]}

\section{Metodologi Penelitian \\ Bahan dan Alat}

Bahan-bahan yang digunakan dalam penelitian ini adalah ALSD, metanol, $\mathrm{BF}_{3}$-dietil eterat, asam sulfat dan etilen glikol. Peralatan utama dalam penelitian yaitu labu leher tiga yang dilengkapi dengan refluks kondensor, termometer dan magnetic stirrer-bar (reaktor), magnetic stirrer, statif dan klem.

\section{Tahap Esterifikasi [2]}

Dimasukkan 150 gram ALSD yang telah dianalisis komposisinya ke dalam reaktor. Ditambahkan metanol dan direaksikan selama 120 menit pada temperatur $70{ }^{\circ} \mathrm{C}$. Perbandingan mol ALSD dan metanol adalah 1:8 dan asam sulfat $1 \%$ (b/b) ALSD. Setelah waktu reaksi tercapai, campuran reaksi dipindahkan ke corong pemisah untuk memisahkan campuran. Lapisan atas dicuci dengan air suling bersuhu $85^{\circ} \mathrm{C}$ hingga $\mathrm{pH}$ netral lalu diuapkan untuk memisahkan metanol dan air yang tersisa. Metil ester yang dihasilkan dianalisis densitas (piknometer), viskositas (viskosimeter Ostwald), bilangan iodin (AOAC 920.158) dan komposisinya (GC-MS).

\section{Tahap Polimerisasi [20]}

Dimasukkan 100 gram metil ester yang telah dianalisis bilangan iodinnya ke dalam reaktor. Ditambah katalis $\mathrm{BF}_{3}$-dietil eterat dengan konsentrasi 9,2\% (b/b) metil ester. Reaksi polimerisasi dilangsungkan pada temperatur 126$132^{\circ} \mathrm{C}$ dengan variasi waktu reaksi 3,4 dan 5 jam. Metil ester terpolimerisasi dianalisis bilangan iodinnya untuk mengetahui terjadinya reaksi polimerisasi.

\section{Tahap Poliesterifikasi [20]}

Setelah waktu reaksi polimerisasi tercapai, ditambahkan etilen glikol dengan perbandingan berat 1:1 ke dalam reaktor. Reaksi poliesterifikasi berlangsung pada temperatur $175-200^{\circ} \mathrm{C}$ dan waktu reaksi 4 jam. Dilakukan analisis bilangan asam (ASTM D4662-03) dari campuran tiap satu jam. Poliester yang diperoleh dianalisis viskositas (viscotester VT-04F), berat molekul (metode 
gugus ujung), gugus fungsi (FT-IR) dan komposisinya (GC).

\section{Hasil dan Pembahasan}

Karakteristik Bahan Baku

Bahan awal yang digunakan untuk sintesis poliester adalah metil ester hasil esterifikasi ALSD dengan metanol menggunakan katalis asam sulfat. Hasil analisis kromatogram GC-MS ALSD disajikan dalam gambar 4.

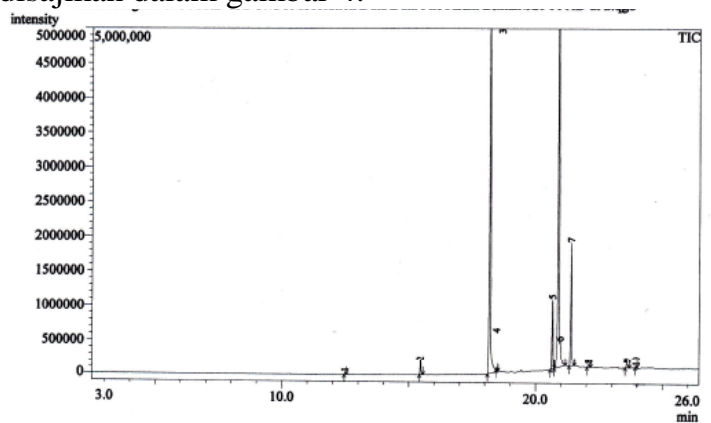

Gambar 4. Hasil Kromatogram GC-MS ALSD

ALSD yang digunakan memiliki berat molekul 270,836 g/mol dan mengandung 53,27\% asam lemak tak jenuh. ALSD ini selanjutnya akan diesterifikasi menghasilkan metil ester. Hasil analisis GC-MS terhadap metil ester ALSD disajikan dalam gambar 5 .

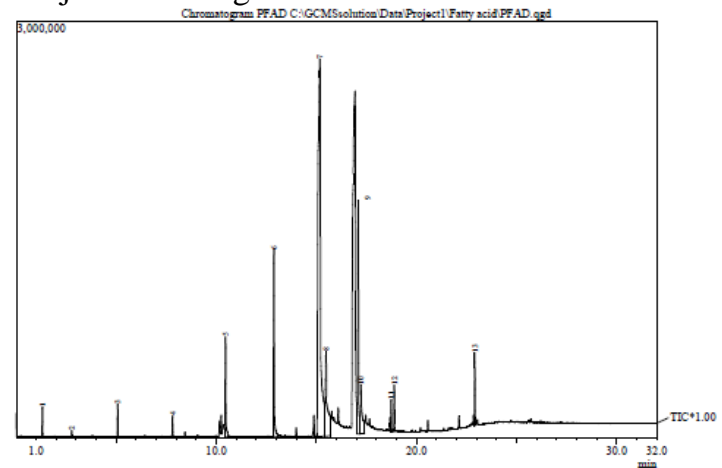

Gambar 5. Hasil Kromatogram GC-MS Metil Ester

Hasil analisis GC-MS menunjukkan kemurnian metil ester yang dihasilkan yaitu sebesar 82,23\% dan berat molekul 267,97 g/mol. Metil ester ini selanjutnya akan digunakan sebagai bahan baku poliester. Hasil analisis karakteristik metil ester ALSD ditunjukkan pada tabel 1.

Tabel 1. Hasil analisis metil ester ALSD

\begin{tabular}{|l|c|}
\hline \multicolumn{1}{|c|}{ Parameter } & Hasil \\
\hline Bilangan Iodin & $77,29 \mathrm{~g} \mathrm{I}_{2} / 100 \mathrm{~g}$ \\
\hline Viskositas $\left(30^{\circ} \mathrm{C}\right)$ & $6,90 \mathrm{cP}$ \\
\hline Densitas $\left(30^{\circ} \mathrm{C}\right)$ & $859,91 \mathrm{~kg} / \mathrm{m}^{3}$ \\
\hline
\end{tabular}

\section{Sintesis Poliester ALSD}

Reaksi polimerisasi metil ester dilakukan dengan menggunakan katalis boron trifluorida dietil-eterat. Poliester yang dihasilkan berbentuk gel, kental, bewarna coklat kehitaman dan bertekstur padat pada suhu ruangan.

\section{Hasil Analisis Spektrum FT-IR dan} Kromatogram GC Poliester

Poliester yang disintesis memiliki gugus molekul yang bisa diidentifikasi dengan menggunakan FT-IR (Fourier Transform InfraRed). Hasil analisis spektrum FT-IR ditunjukkan pada gambar 6.

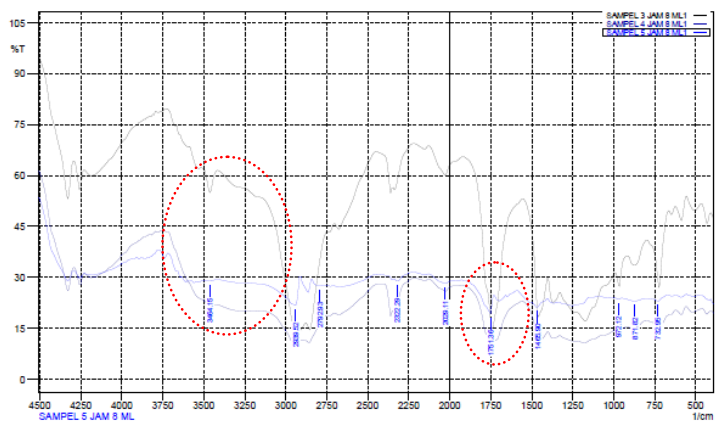

Gambar 6. Spektrum FT-IR Poliester

Suatu senyawa ester dicirikan dengan adanya serapan ulur $\mathrm{C}=\mathrm{O}, \mathrm{C}-\mathrm{O}$ dan $\mathrm{OH}$ yang khas [1]. Terbentuknya poliester ditandai dengan terbentuknya puncak vibrasi pada bilangan gelombang $1751,36 \mathrm{~cm}^{-1}$ menunjukkan pita uluran $\mathrm{C}=\mathrm{O}$ ester untuk semua variasi waktu reaksi. Perbedaan antara gugus $\mathrm{C}=\mathrm{O}$ asam dan gugus $\mathrm{C}=\mathrm{O}$ ester adalah pada gugus $\mathrm{C}=\mathrm{O}$ asam muncul pada bilangan gelombang 1730-1700 $\mathrm{cm}^{-1}$ sedangkan pada gugus $\mathrm{C}=\mathrm{O}$ ester muncul pada bilangan gelombang 1760-1735 $\mathrm{cm}^{-1}$ [21]. Bukti lain telah terbentuk ester adalah melemahnya spektra karakteristik dari gugus $\mathrm{OH}$ ikatan hidrogen yang membentuk pita yang melebar pada bilangan gelombang sekitar $3500 \mathrm{~cm}^{-1}-3400 \mathrm{~cm}^{-1}$ karena reaksi poliesterifikasi. Terjadinya reaksi polimerisasi ditandai dengan tidak adanya pita serapan vinil $\quad\left(-\mathrm{CH}=\mathrm{CH}_{2}-\right)$ pada pada bilangan gelombang $990 \mathrm{~cm}^{-1}-910 \mathrm{~cm}^{-1}$. Hal ini menandakan bahwa pada reaksi polimerisasi terjadi pemutusan ikatan rangkap.

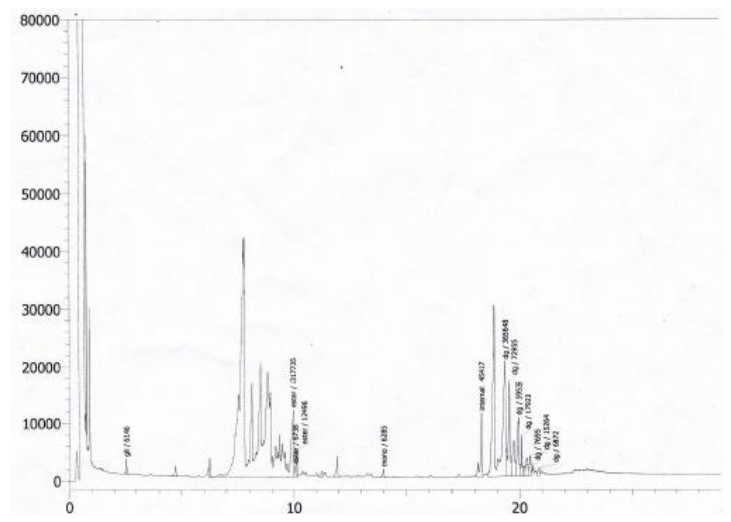

Gambar 7. Hasil Analisis Kromatogram GC Poliester 
Hasil yang menguatkan bahwa telah terbentuk gugus poliester diperlihatkan pada hasil kromatogram GC poliester pada gambar 7. Hasil analisis GC menunjukkan kemurnian poliester yang dihasilkan yaitu sebesar $65,49 \%$.

\section{Pengaruh Waktu Reaksi Polimerisasi Terhadap Bilangan Iodin}

Pengaruh waktu reaksi polimerisasi terhadap bilangan iodin metil ester diperlihatkan pada gambar 8 .

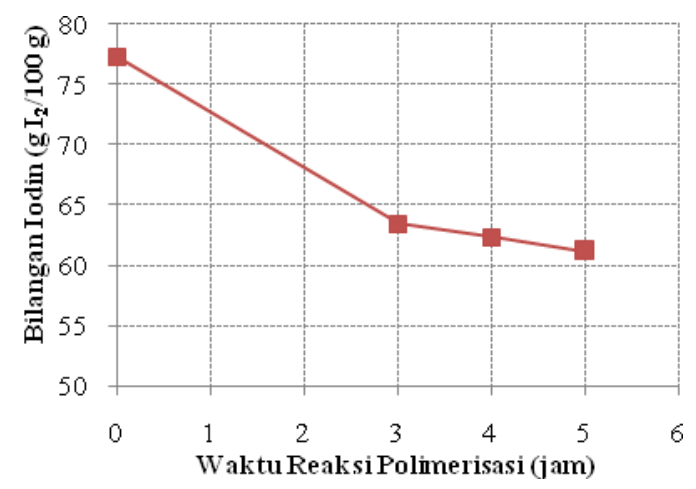

\section{Gambar 8. Pengaruh Waktu Reaksi Polimerisasi Terhadap Bilangan Iodin Metil Ester Terpolimerisasi}

Pada gambar 8 bilangan iodin cenderung menurun dengan meningkatnya waktu reaksi. Parameter yang paling penting diperhatikan dalam pembentukan suatu polimer adalah banyaknya ikatan rangkap yang ada pada sampel yang dapat ditunjukkan oleh bilangan iodin.

Dengan semakin bertambahnya waktu reaksi maka harga bilangan iodin akan semakin kecil [3]. Hal ini sesuai dengan hasil yang diperoleh pada penelitian ini. Selain itu, penurunan bilangan iodin dapat diamati secara visual yaitu dengan terjadinya perubahan warna pada sampel. Nilai bilangan iodin akan berpengaruh pada penampilan minyak, semakin tinggi bilangan iodin maka semakin jernih penampilan minyak tersebut [6]. Penurunan bilangan iodin mengakibatkan warna sampel menjadi lebih gelap.

Hasil penelitian menunjukkan dengan bertambahnya waktu reaksi, pengurangan bilangan iodin hanya sedikit berbeda. Hal ini mengindikasikan bahwa pertambahan waktu reaksi polimerisasi kurang berpengaruh pada penurunan bilangan iodin.

\section{Pengaruh Waktu Reaksi Poliesterifikasi Terhadap Bilangan Asam Poliester}

Pengaruh waktu reaksi poliesterifikasi terhadap bilangan asam poliester diperlihatkan pada gambar 9 .

Pada gambar 9 bilangan asam menurun seiring dengan bertambahnya waktu reaksi poliesterifikasi. Analisis bilangan asam dilakukan untuk mengetahui perkembangan reaksi poliesterifikasi. Reaksi dianggap telah berlangsung jika bilangan asam mengalami penurunan. Penurunan bilangan asam ini terjadi akibat perpanjangan rantai reaktif karboksil membentuk polimer [9].

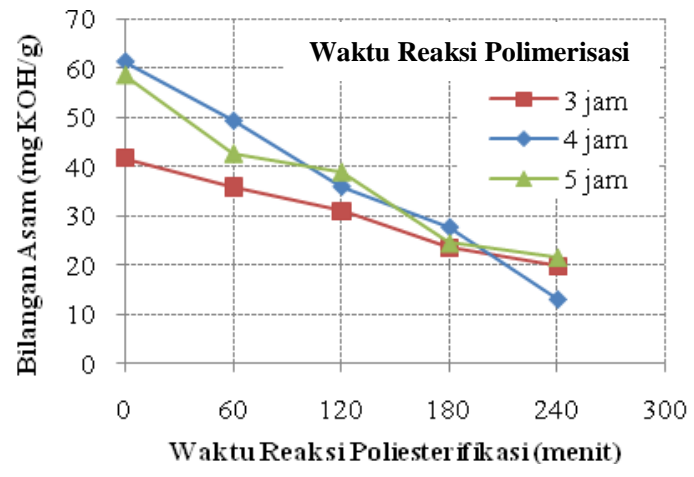

Gambar 9. Pengaruh Waktu Reaksi Poliesterifikasi Terhadap Bilangan Asam Poliester

Bilangan asam dapat digunakan sebagai parameter kualitas poliester yang dihasilkan. Semakin tinggi bilangan asam maka kualitas poliester yang dihasilkan akan semakin buruk. Hal ini disebabkan oleh tingginya bilangan asam menunjukkan tingginya kemampuan suatu bahan dalam menyerap air [9]. Poliester komersial yang beredar di pasaran memiliki standard bilangan asam $\leq 32 \mathrm{mg} \mathrm{KOH} / \mathrm{g}$ [18]. Hasil yang diperoleh pada penelitian ini memiliki nilai bilangan asam $\leq 32 \mathrm{mg} \mathrm{KOH} / \mathrm{g}$, maka hal ini menunjukkan diperolehnya poliester dengan kualitas bilangan asam yang baik.

\section{Pengaruh Waktu Reaksi Polimerisasi Terhadap Viskositas Poliester}

Pengaruh waktu reaksi polimerisasi terhadap viskositas poliester diperlihatkan pada gambar 10.

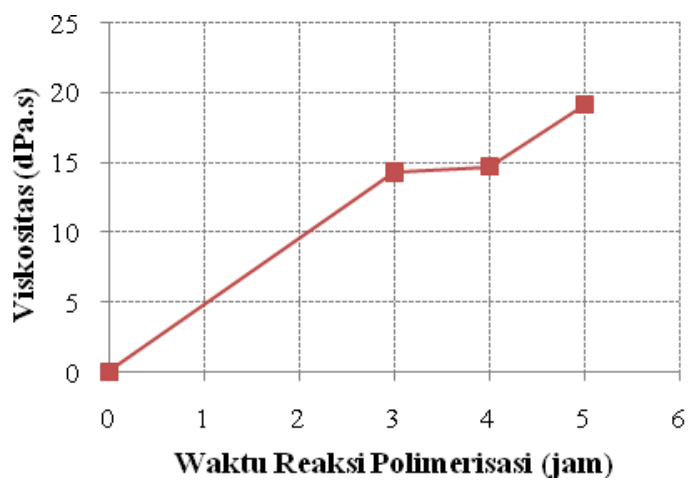

Gambar 10. Pengaruh Waktu Reaksi Polimerisasi Terhadap Viskositas Poliester 
Pada gambar 10 viskositas semakin meningkat dengan meningkatnya waktu reaksi polimerisasi. Viskositas merupakan ukuran kekentalan suatu bahan untuk mengalir. Dengan semakin bertambahnya waktu reaksi, viskositas akan semakin bertambah [14]. Dalam reaksi poliesterifikasi sulit untuk menjaga agar reaksi bergerak ke arah produk karena konversi reaktan akan cenderung meningkat selama reaksi. Hal ini cenderung mengakibatkan pertambahan viskositas dalam media reaksi pada konsentrasi tinggi [9]. Hal ini sesuai dengan hasil yang diperoleh pada penelitian ini.

\section{Pengaruh Waktu Reaksi Polimerisasi Terhadap Berat Molekul Poliester}

Pengaruh waktu reaksi polimerisasi terhadap berat molekul poliester diperlihatkan pada gambar 11 .

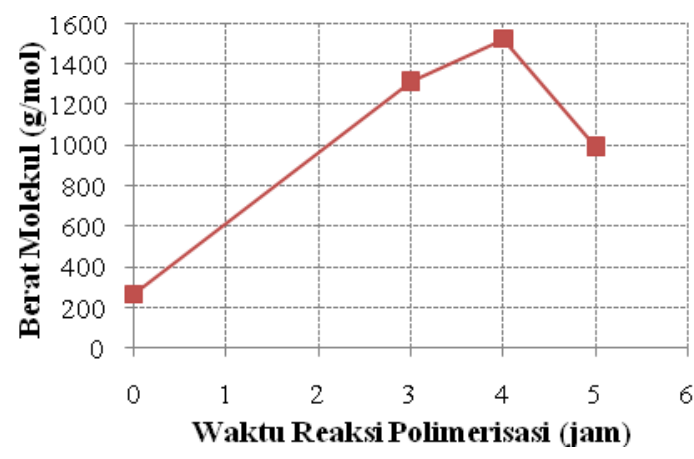

Gambar 11. Pengaruh Waktu Reaksi Polimerisasi Terhadap Berat Molekul Poliester

Pada gambar 10 berat molekul berfluktuasi seiring dengan meningkatnya waktu reaksi. Berat molekul polimer merupakan perhatian utama dalam praktek pembuatan polimer. Poliester memiliki gugus ujung berupa gugus karboksil dan hidroksil pada ujung lainnya [22]. Zhang, dkk.(1994) menggunakan metode analisis gugus ujung untuk menentukan berat molekul dalam sintesis polikaprolakton [23]. Berat molekul poliester pada penelitian ini juga ditentukan dengan metode gugus ujung.

Reaksi poliesterifikasi merupakan reaksi polikondensasi yang bersifat reversible [9]. Semakin lama waktu reaksi maka kemungkinan kontak antar zat semakin besar sehingga akan menghasilkan konversi yang besar. Jika kesetimbangan reaksi sudah tercapai maka dengan bertambahnya waktu reaksi tidak akan menguntungkan karena tidak akan memperbesar hasil [15].

Hasil penelitian menunjukkan peningkatan berat molekul seiring dengan bertambahnya waktu reaksi polimerisasi. Akan tetapi pada waktu reaksi polimerisasi 5 jam terjadi penurunan berat molekul.
Diduga terjadinya penurunan berat molekul ini disebabkan oleh semakin lamanya waktu polimerisasi menyebabkan bertambahnya viskositas campuran yang akan mengurangi efisiensi pengurangan molekul metanol sehingga cenderung akan mengurangi laju reaksi mengakibatkan kondisi kesetimbangan pembentukan poliester berbalik membentuk reaktan kembali [9]. Selain itu, diduga juga dapat disebabkan oleh terjadinya reaksi antara polimer dengan monomer membentuk polimer dengan rantai yang lebih pendek [23].

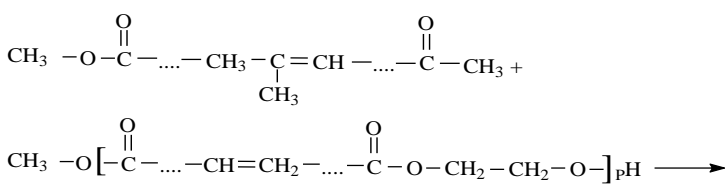

$\mathrm{CH}_{3}-\mathrm{O}\left[\stackrel{\mathrm{OI}}{\mathrm{C}}-\ldots . . \mathrm{CH}=\mathrm{CH}_{2}-\ldots . \stackrel{\mathrm{O}}{\mathrm{C}}-\mathrm{O}-\mathrm{CH}_{2}-\mathrm{CH}_{2}-\mathrm{O}-\right]_{\mathrm{m}} \mathrm{H}+$ $\mathrm{CH}_{3}-\mathrm{O}\left[-\stackrel{\mathrm{O}}{\mathrm{C}}-\ldots . . \mathrm{CH}=\mathrm{CH}_{2}-\ldots . . \stackrel{\mathrm{O}}{\mathrm{C}}-\mathrm{O}-\mathrm{CH}_{2}-\mathrm{CH}_{2}-\mathrm{O}-\right]_{n} \mathrm{H}$

\section{Gambar 12. Reaksi monomer dan polimer}

Poliester dengan berat molekul tinggi umumnya linear, bersifat polimer termoplastik dengan berat molekul $10.000-30.000 \mathrm{~g} / \mathrm{mol}$. Poliester berat molekul tinggi dapat digunakan untuk aplikasi powder coating dan drying binder pada cat. Poliester dengan berat molekul rendah yaitu diantara 500-7000 g/mol. Poliester dengan berat molekul rendah mungkin dapat berupa rantai linear atau bercabang dengan gugus ujung hidroksil dan karboksil. Untuk tujuan khusus, poliester dengan berat molekul rendah 1000-5000 $\mathrm{g} / \mathrm{mol}$ lebih banyak dimodifikasi karena memilki gugus fungsional karboksil dan hidroksil yang lebih reaktif dibandingkan poliester dengan berat molekul tinggi [13].

Hasil penelitian menunjukkan poliester yang dihasilkan memiliki rentang 995,03-1522,07 $\mathrm{g} / \mathrm{mol}$. Sehingga hasil poliester yang dihasilkan tergolong poliester dengan berat molekul rendah yang lebih cocok digunakan untuk aplikasi poliester termodifikasi. Rendahnya berat molekul poliester yang dihasilkan disebabkan oleh bahan baku yang digunakan adalah metil ester ALSD yang memiliki ikatan rangkap yang rendah.

\section{Kesimpulan}

Kesimpulan yang dapat diambil dari penelitian yang telah dilakukan diantaranya adalah poliester yang dihasilkan dari ALSD memiliki sifat fisik mendekati poliester komersial yaitu berbentuk gel, kental, bewarna coklat kehitaman dan bertekstur padat pada suhu ruangan, memiliki kualitas bilangan asam yang baik dan tergolong poliester dengan berat molekul rendah yang lebih cocok digunakan untuk aplikasi poliester 
termodifikasi. Reaksi pembentukan poliester merupakan reaksi reversible dimana perolehan produk sangat bergantung pada waktu reaksi polimerisasi.

\section{Daftar Pustaka}

[1] Agung Nugraha, "Sintesis Ester Glukosa Oleat antara Glukosa Pentaasetat dan Metil Oleat." Skripsi, Departemen Kimia, FMIPA, IPB, Bogor, 2006.

[2] Alfitra. Pembuatan Biodiesel dari Palm Fatty Acid Distillate (PFAD) dengan Katalis Asam. http://repository.usu.ac.id. Diakses pada 12 Mei 2012.

[3] Aniek S. Handayani; Sidik Marsudi; M. Nasikin dan M. Sudibandriyo. "Reaksi Esterifikasi Asam Oleat dan Gliserol Menggunakan Katalis Asam." Jurnal Sains Materi Indonesia, Edisi Khusus Oktober, 2006 : hal. 102-105.

[4] Croston, C. B.; I. L. Tubb; J. C. Cowan and H. M. Teeter. "Polymerization Of Drying Oils. VI. Catalytic Polymerization Of Fatty Acids and Esters With Boron Trifluoride and Hydrogen Fluoride." Journal of the American Oil Chemist's Society. Volume 29, Number 8, DOI: 10.1007/BF02639812, 1952 : hal. 331333.

[5] Desi Suci Handayani, Triana Kusumaningsih, Muslimin. "Sintesis Kopoli (Anetol-DVB) Sulfonat Sebagai Bahan Alternatif Resin Penukar Kation". Jurusan Teknik Pertanian. Vol. 17(2), Bogor, 2002. hal. 43-48.

[6] Saulina Dwitri, "Pembuatan Minyak Goreng dari RBD-Minyak Sawit Tanpa Pemisahan Olein dan Stearin dengan Cara Reaksi Interesterifikasi dengan Minyak Nabati Cair." Tesis Program Pascasarjana, USU, Medan, 2003.

[7] Fred W. Billmeyer, Textbook of Polymer Science, Second Edition, (New York: John Wiley and Sons, Inc., United States of America, 1971).

[8] Freedman, B. E. H, T. L. Mounts, "Variabel Affecting the Yields of Fatty Esters from Transesterified Vegetable Oils". J. Am. Oil Chem. Soc., 61, 1984. hal 1638-1643.

[9] George Odian, Principles of Polymerization, Fourth Edition, (New York: John Wiley \& Sons, Inc., 2004).

[10] Giwangkara E. G. Kegunaan Hidrokarbon dalam Kehidupan Sehari-hari, http://kimiaaplikasi.wordpress.com. 2007. Diakses 27 Maret 2012.

[11] Gregorio C. Gervajio, Fatty Acid and Derivatives from Coconut Oil dalam Bailey's Industrial Oil and Fat Products, Volume 6.
Sixth Edition. Editor: Fereidoon Shahidi. (New York: John Wiley and Son, 2005).

[12] Guerino G. Sacripante, Alan E. J. Toth, Marko D. Saban, "Polyesters". US Patent: 6.180.747 b1. Jan 30, 2001.

[13] H.F. Huber dan D. Stoye. Polyesters- Coating Technology Handbook. Third Edition. Taylor \& Francis Group, LLC, 2006.

[14] Hüseyn Topallar, Yüksel Bayrak, Mehmet Iscan. Tr. J., Chemistry 21, 1997. hal.118-125.

[15] James Silitonga, Ida Zahrina, Yelmida. Esterifikasi Palm Fatty Acid Distillate (PFAD) Menjadi Biodiesel Menggunakan Katalis M-Zeolit Dengan Variabel Waktu Reaksi dan Kecepatan Pengadukan. http://repository.unri.ac.id. Diakses 5 Mei 2013.

[16] Juliati Tarigan, "Ester Asam Lemak", Karya Ilmiah, Jurusan Kimia FMIPA USU, Medan, 2009.

[17] Kurniasih. "Pemanfaatan Asam Lemak Sawit Distilat Sebagai Bahan Baku Dietanolamida Menggunakan Lipase (Rhizomucor meihei)." Tesis, Sekolah Pascasarjana, Universitas Sumatera Utara, Medan, 2008.

[18] National Petrochemical Campany/Shahid Tondguyan Petrochemical Complex. http://nipc.ir. Diakses pada 5 Mei 2013.

[19] Nukhe Andri Silviana. "Analisis Kadar Asam Lemak Bebas dari Palm Fatty Acid Distillate (PFAD) dan Coconut Fatty Acid Distillate (CFAD)." Karya Ilmiah, Departemen Kimia, FMIPA, USU, Medan, 2008.

[20] Nurmian, Yusmiati Pane, Nurhasanah, "Sintesis Poliester Dari Minyak Goreng Yang Berasal Dari Crude Palm Oil (CPO)." Laporan Penelitian Jurusan Teknik Kimia, Universitas Sumatera Utara, Medan, 2000.

[21] Pavia L. D, Lampman G. M, Kriz G. S, Introduction to Spectroscopy, Second Edition, (Washington: W.B. Saunders, 1996).

[22] Prima Astuti Handayani, "Polimerisasi Akrilamid Dengan Metode Mixed-Solvent Precipitation Dalam Pelarut Etanol-Air". Volume 8, No.1, 2010.

[23] Qijin Zhang, Wenying X.V., Zhiyong WANG, "Synthesis of Polycaprolactone With Two Carboxyl End Group". Journal Matter Sci. Technol, Vol 10, 2010.

[24] William W. Christie, "Preparation Of Ester Derivatives Of Fatty Acids For Chromatographic Analysis", The Scottish Crop Research Institute, Invergowrie, Scotland DD2 5DA, 1993. 